\title{
手関節尺側部痛に対する尺骨短縮術の治療成績
}

\author{
長崎大学医学部整形外科 \\ 櫛 田学・今 村 宏太郎 \\ 長 谷 芳 文 \\ 愛野記念病院整形外科 \\ 平 野 英 二
}

\section{Ulnar Shortening Osteotomy for Ulnar Wrist Pain}

by

\author{
Manabu Kushida, Kotaro Imamura and Yoshifumi Nagatani \\ Department of Orthopedic Surgery \\ Nagasaki University School of Medicine
}

Eiji Hirano

Department of Orthopaedic Surgery

Aino Memorial Hospital

We reviewed the clinical symptoms and the radiographical findings of patients complaing of ulnar wrist pain and evaluated the results of ulnar shortening osteotomy for this disorder.

Since 198810 patients had ulnar shortening osteotomy, nine male and one female, with an average age of 30.2 years (range : 14-66). These patients complained of severe pain in the ulnar side of the wrist in spite of conservative treatment. On preoperative roentgenograms, the average ulnar variance was $+2.5 \mathrm{~mm}$ ranging from $-2.0 \mathrm{~mm}$ to $+6.0 \mathrm{~mm}$. Arthrography was performed on all 11 wrists and MRI in 3 wrists. These examinations indicated perforation of the Triangular Fibrous Cartilage Complex in 7 wrists. The average duration of follow-up was 12.4 months, ranging from 7 to 20 months.

Using Cooney's clinical scoring system, the average clinical score was 89 , ranging from 53 to 59 (full mark 100 points). No one complained of pain. All patients returned to their original occupation. In two patients with disorder of the distal radioulnar joint, the range of pronation and supination was restricted. Postoperative roentgenograms showed the average ulnar variance to be $+0.2 \mathrm{~mm}$ ranging from $-4.0 \mathrm{~mm}$ to $2.0 \mathrm{~mm}$. The average amount of ulnar shortening was $+2.5 \mathrm{~mm}$ ranging from $1.5 \mathrm{~mm}$ to $6.0 \mathrm{~mm}$. No significant correlation was found between the postoperative ulnar variance, the amount of ulnar shortening and clinical results.

Ulnar shortening osteotomy is considerd a useful procedure for patients with ulnar wrist pain.

目

的

我々は，手関節の尺側に痛みを訴える、いわゆる ulnocarpal abutment syndromeの患者に対して 1988 年以来尺骨短縮骨切り術 (Milch 法 ${ }^{3)}$ ) を行ってきた. 今回はその手術成績を調査し, 本術式の有用性につい
て検討を加えた。

\section{対象と方法}

症例は, 男性 9 例 10 関節, 女性 1 例 1 関節, 年齢は, 14 歳より 66 歳 (平均 30.2 歳) であった。罹患側は右 5 関節，左 6 関節で，いずれもギプス固定などの保存 
的療法で症状が軽快しなかった症例である. 症状発現 から手術までの期間は 3 力月より 14 力月(平均 6.8 力 月）であった。

手関節中間位の正面 X線像で計測した ulnar variance $\left(\right.$ Palmer 法 $^{5)}$ ) は $-2.0 \mathrm{~mm}$ より $6.0 \mathrm{~mm}$ (平均十 2 . $5 \mathrm{~mm})$ であった。骨折や骨端線損傷の既往があるものは 3 例あった，尺骨頭の骨硬化，cyst などを認めたもの は 3 関節, 月状骨尺側に cyst を認めたものも 3 関節で あった。また，遠位橈尺関節に不適合を認めたものは 2 関節であった。

この 10 例 11 関節の臨床成績を, 疼痛, 復職の状況, 可動域, 握力の各項目ごとに評価する Cooney $^{2)}$ の基準 を用いて判定した。また，術前術後の ulnar variance より，短縮量を決定し，これと治療成績との関係につ いても調べた。

術後経過観察期間は 7 力月より 20 力月（平均 11.4 カ月）であった。

$$
\text { 結果 }
$$

疼痛については，術前に中等度の疼痛をうつかえた もの 5 関節，耐えられないほどの疼痛を訴えたもの 6 関節であった. 術後は疼痛の全くないもの 7 関節, 時

(点)

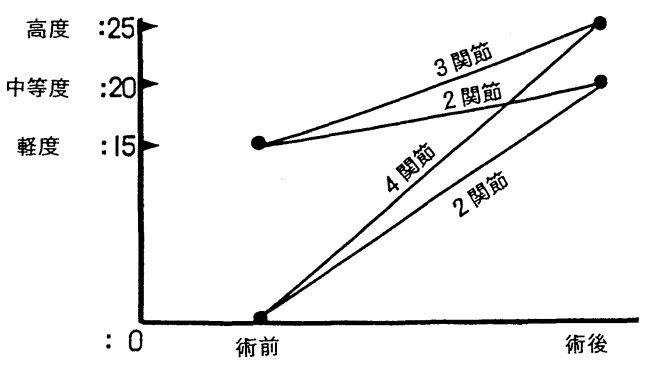

図 $1:$ 疼痛の変化

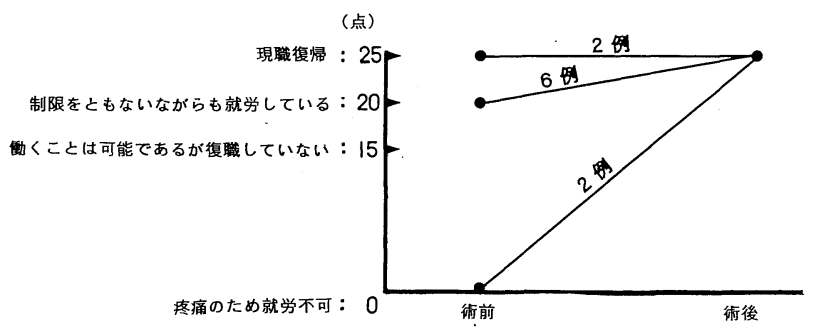

図 2 : 復職の状況
に軽度の疼痛を訴えるもの 4 関節であり, 疼痛の改善 は良好であった（図 1 )。

復職の状況に関しては, 漁船員と土木作業員の各 1 例が, 術前は疼痛のため休職していたが, 術後は問題 なく仕事が可能となった。また，残り 8 例も全例現職 へ復職している (図 2 ).

前腕の回外回内の可動域については, 術前健側比 $100 \%$ ものが 6 関節，75～100\%のもの 2 関節， 50〜 $75 \%$ \%の 1 関節, $50 \%$ 未満のもの 2 関節であっ た. 術後は $100 \%$ の可動域となったものは 9 関節あっ たが，他の 2 関節の可動域は $80 \%$ と.56\%であり，そ の改善は十分ではなかった(図 3 )。この 2 関節はいず れも遠位橈尺関節に不適合を認める症例であった。

手関節の掌背屈は, 術前, 健側比 $100 \%$ ものが 5 関節，75〜100\%のものが 3 関節，50〜 $75 \%$ \%のが 3 関節であった。術後は 1 例を除き健側比 $100 \%$ の可 動域をえることができた（図 4 ）。

術前の握力は健側比 $100 \%$ $\%$ の 1 関節， 75〜 100 \%のもの 4 関節, 50〜 $75 \%$ \%の 5 関節, $50 \%$ 末満の もの 1 関節であった。術後は健側比 $100 \%$ もの 5 関 節，75〜100\%のもの 5 関節，50〜 75\%のもの 1 関節 であった（図 5 ).

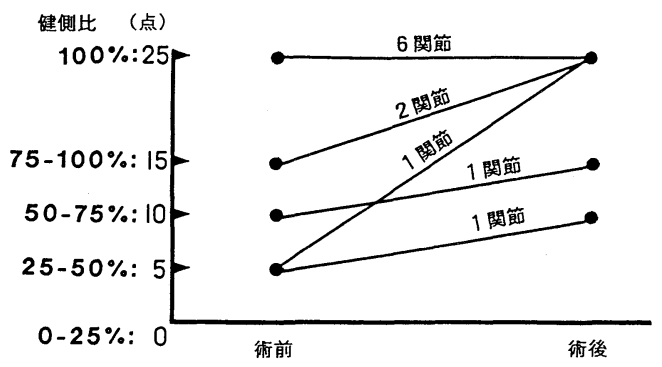

図 3 : 可動域（前腕回内十回外）

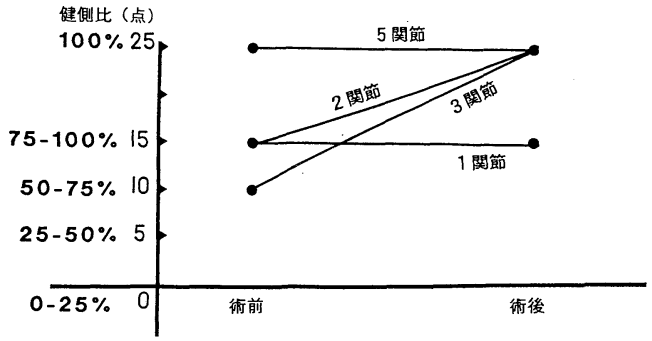

図 4：可動域（手関節掌屈十背屈） 


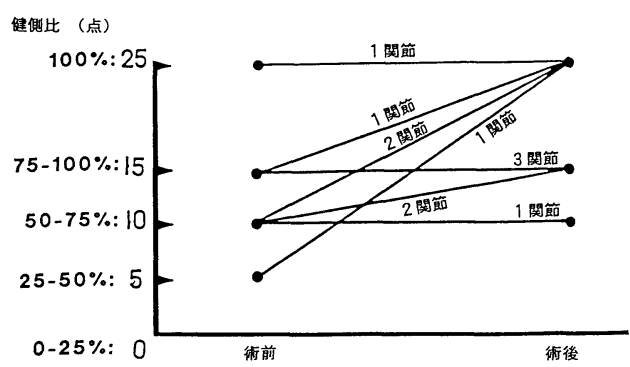

図 5：握力の変化

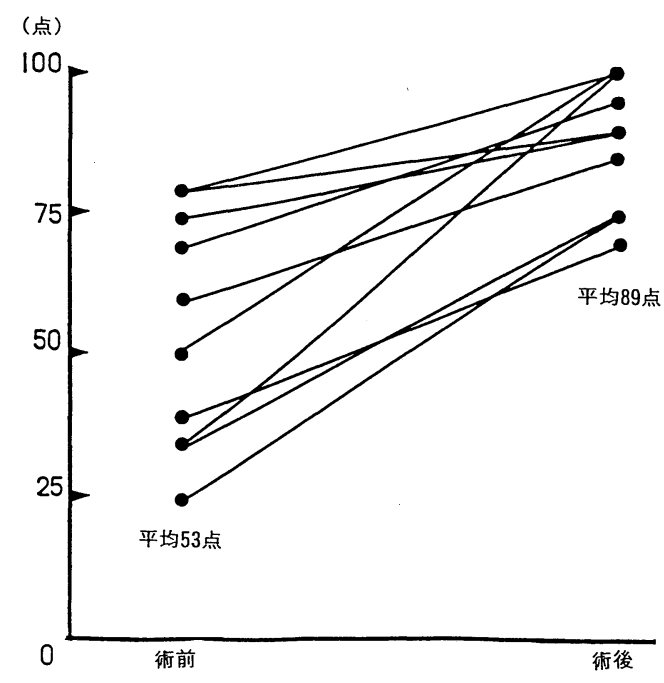

図 6：総合評価

総合評価では，すべての症例で改善が認められ，平 均では術前の 53 点が術後 89 点と 36 点の改善をみた (図 6 ).

ulnar variance は術前平均 $+2.5 \mathrm{~mm}$ が術後平均 -1 . $0 \mathrm{~mm}$ となり, 短縮長は平均 $3.5 \mathrm{~mm}$ であったが (図 7 ), 尺骨の短縮長と術後成績との間に明らかな相関はみら れなかった（図 8).

\section{考 察}

今回の予後調查では, 全ての症例において症状の改 善が得られ, 総合評価でも, 術前平均 53 点が術後平均 89 点と著しい改善を認め, 尺骨短縮骨切り術は, 手関 節尺側部痛にたいする有用な手術法であると考える.

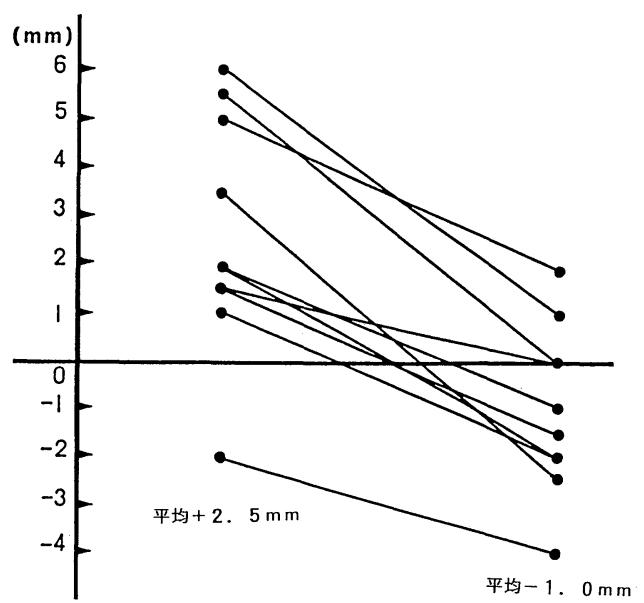

術前

術後

図 7 : Ulnar variance

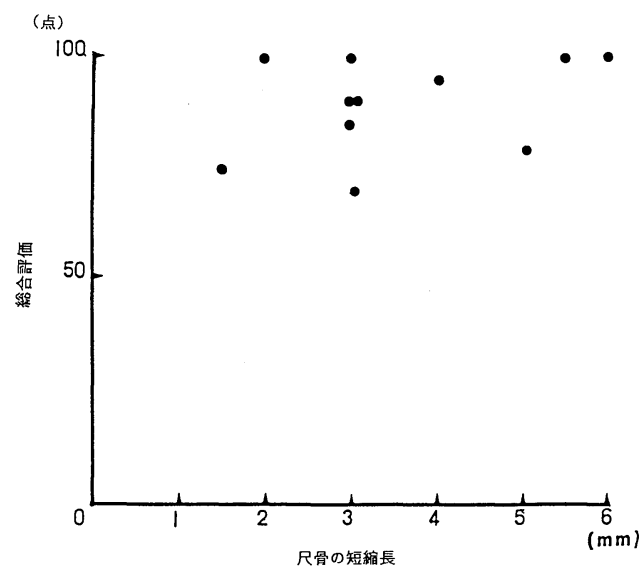

図 8 : 尺骨の短縮長と総合評価との関係

症状の改善を項目別にみていくと, 疼痛, 復職, 手関 節掌背屈運動については満足できるものであったが, 前腕の回内回外の可動域, 握力については改善の十分 でない症例もみられた。阿部1らは, 本術式の適応を若 年者で回旋障害の少ないものとし, 中村 ${ }^{4} ら も$ 遠位橈 尺関節に変形性関節症や破壊のないものとしている. 今回の我々の場合も, 前腕の回内回外の不十分であっ た症例は，遠位橈尺関節に不適合がみられたものであ り，したがって遠位橈尺関節に不適合が存在する場合 は本術式の適応は慎重にすべきであろう。

先に述べたように，尺骨の短縮長と術後成績の間に は相関がみられず, 尺骨短縮術における適切な短縮長, 及び術後の適切な ulnar variance を決定することは 
できなかった. Palmer ${ }^{6)}$ の研究によれば, Trianguiar Fibrous Cartilage (以下 TFC) が正常の場合, 尺骨を $1 \mathrm{~mm}$ 短縮することにより TFC に加わる負荷は約 10 \%免荷され， $2 \mathrm{~mm}$ 短縮すると約 $15 \%$ 免荷される. した がって $2 \sim 3 \mathrm{~mm}$ 短縮によって十分な免荷が得られる と考元, 最近の症例では必ずしも zero variance へ戻 すことを目標としていない.

\section{ま と め}

1. 手関節尺側部痛を訴えた 10 例 10 関節にたいし て行った尺骨短縮術の手術成績を調査し, 本術式の有 用性について検討した。

2. 全例で, 症状の改善を認め, ほぼ満足すべき結 果が得られた。

3. 疼痛に比べ, 可動域の改善はやや不十分で, 特 に遠位橈尺関節に不適合が存在する症例での可動域の 改善は十分ではなかった。

4. 従って, 遠位橈尺関節に不適合が存在する症例 への本術式の適応は慎重でなせればならない.

\section{参 考 文 献}

1）阿部宗昭・他：遠位橈尺関節障害に対する Milch 手
術. 日手会誌，3：524-529， 1986 .

2) Cooney, W.P., et al.: Difficult wrist fractures. Perilunate fracture-dislocations of the wrist. Clin. Orthop., 214:136-147, 1987.

3) Milch, $\mathrm{H}$ : Cuff resection of the ulna for malunited colles' fracture. J. Bone Joint Surg., $23: 311-313$, 1941.

4）中村苶吾・他：尺骨短縮術と Sauve-Kapanji 手術. 日手会誌，6：713-716，1989.

5) Palmar, A. K. et al. : Relationship between ulnar variance and triangular fibrocartilage complex thickness. J Hand Surg. 9A:681-683, 1984.

6) Palmer, A. K., et al. : Partial excision of the triangular fibrocartilage complex J. Hand Surg., 13A:403-406, 1988.

質 問 鹿児島大学整形外科 牧 辰哉

$-2 \mathrm{~mm}$ variance の症例に対し尺骨骨切り術をやっ ていますが，術後一 $4 \mathrm{~mm}$ varianceになってはかえっ て，遠位橈尺骨不適合をきたすのではないですか？

自験例では不適合はみられませんでした。 